ROCZNIKI PEDAGOGICZNE

Tom 12(48), numer $3-2020$

DOI: https://doi.org/10.18290/rped20123-9

\title{
OJCOSTWO W SAMOOCENIE MĘŻCZYZN WYCHOWUJĄCYCH DZIECI Z USZKODZONYM SŁUCHEM CZESŚĆ II. BADANIA EMPIRYCZNE
}

Wyniki badań prezentowanych $\mathrm{w}$ niniejszym artykule dotyczą ojców dzieci z uszkodzeniem słuchu. Wydawało się bowiem, że ważne jest dotarcie do nich jako do grupy będącej rzadziej podmiotem badań niż matki tych dzieci. Ponadto, badania nad funkcjonowaniem matek dzieci niesłyszących w ich roli rodzicielskiej oraz czynniki, które mają na to wpływ, nie mogą być uogólnione na grupę ojców, gdyż matki odgrywają większą rolę w codziennej opiece nad swoimi dziećmi, a ich role domowe i macierzyńskie różnią się od roli mężczyzny w domu oraz od jego roli ojcowskiej (np. Klaczak, 1996, Zaidman-Zait i in., 2016) ${ }^{1}$. Obecne badania nie mają charakteru porównawczego, ale realizują cel deskryptywny. Celem podjętych przez autorki badań empirycznych było poznanie oceny ojców słyszących ich własnych postaw, jakie przyjmują wobec swojego dziecka z uszkodzonym słuchem, oraz ich zaangażowania na rzecz wspomagania jego rozwoju.

Dr hab. Dorota Kornas-Biela, prof. KUL - Katedra Pedagogiki Specjalnej, Instytut Pedagogiki, Wydział Nauk Społecznych, Katolicki Uniwersytet Lubelski Jana Pawła II; adres do korespondencji: Al. Racławickie 14, 20-950 Lublin; e-mail: dorota@biela.pl; ORCID: https://orcid. org/0000-0001-6002-1901.

Mgr KATARZYNA TUPAJ - magister pedagogiki Katolickiego Uniwersytetu Lubelskiego Jana Pawła II; adres do korespondencji: e-mail: my_step@wp.pl.

${ }^{1}$ Teoretyczną podstawę pod relacjonowane obecnie badania empiryczne może czytelnik znaleźć w dwóch wcześniejszych opracowaniach autorki: D. Kornas-Biela, 2001, 2016 oraz w artykule znajdującym się w bieżącym numerze Roczników Pedagogicznych: D. Kornas-Biela, „Ojcostwo mężczyzn wychowujących dzieci z uszkodzonym słuchem. Część I". 


\section{EMPIRYCZNY KONTEKST PODJĘCIA BADAŃ}

Motywacją do podjęcia analiz były wyniki wcześniejszych badań postaw rodzicielskich ojców dzieci niesłyszących wykonane $\mathrm{w}$ ramach realizacji pracy dyplomowej na Podyplomowym Studium Surdopedagogiki „Komunikacja Językowa z niesłyszącymi i słabosłyszącymi” w KUL (Gembal, 2001). Autorka pracy, mgr Anna Gembal, zastosowała metodę indywidualnych przypadków. Techniką zbierania informacji był szczegółowy kilkakrotny wywiad $\mathrm{z}$ pięcioma osobami dorosłymi: trzema ojcami dzieci niesłyszących oraz $\mathrm{z}$ dwiema niesłyszącymi osobami dorosłymi wspominającymi swoje dzieciństwo. $Z$ analizy treści wywiadów okazało się, że każdy z ojców prezentuje inną sylwetkę ojcowskiego zaangażowania: 1. Ojciec, który uciekł od rodziny w dniu, w którym dowiedział się o głuchocie córki, obwiniał żonę za jej kalectwo, obecnie alkoholik; 2 . Ojciec młody wiekiem i niedojrzały psychicznie, który opuścił żonę i córkę, gdy stwierdzono u niej niedosłuch, muzyk, aktywny zawodowo, twierdzący, że jego „praca twórcza wymaga spokoju i samotności”, do dziś niezainteresowany dorosłą już córką niesłyszącą; 3. Ojciec, który pozostał w związku z matką dziecka, ale nie potrafił odnaleźć się w roli ojca, uciekał $\mathrm{z}$ domu na służbę (policjant), nie interesował się dziećmi, nie spędzał z nimi czasu, wstydził się niesłyszącej córki, która wspomina swoją samotność, poczucie, że „nie liczyła się dla ojca”, ocenia swoje życie jako „marne”, bo ojciec „nie nauczył mądrości”; 4. Ojciec, który był dla wszystkich w rodzinie, również dla niesłyszącej córki dobry, miał dla niej czas, nigdy nie uderzył, oszczędzał jej siły i nie pozwalał na ciężką fizyczną pracę; 5. Ojciec bardzo zapracowany, ale śledzący nowinki medyczne, szukający pomocy dla niesłyszącej córki u różnych lekarzy i znachorów, pobłażliwy dla niej, aby wynagrodzić jej brak słuchu.

Przedstawione powyżej charakterystyki ojców ukazały wielkie zróżnicowanie ich ojcowskiego zaangażowania, stąd powstał zamysł dalszej empirycznej penetracji tego problemu. W badaniach starano się odpowiedzieć na pytania: 1. Jak ojcowie słyszący postrzegają swoje dziecko niedosłyszące? Jak rozumieją swoje zadania ojcowskie? Jak oceniają siebie jako ojca dziecka z uszkodzonym narządem słuchu? W jaki sposób ojcowie słyszący wspomagają rozwój dziecka? Jakie przyjmują postawy rodzicielskie wobec niego? 


\section{NARZĘDZIA I GRUPA BADANA}

Badania empiryczne ojców dzieci niesłyszących zostały przeprowadzone wiosną 2015 r. w ramach realizacji pracy magisterskiej przez Katarzynę Bulicz $^{2}$ (2015). Celem uzyskania odpowiedzi na postawione wyżej pytania zastosowano metodę sondażu diagnostycznego przy użyciu kwestionariusza ankiety własnej konstrukcji (D. Kornas-Biela, K. Bulicz) ${ }^{3}$ oraz Kwestionariusza dla Rodziców Marii Ziemskiej (1973, 1981). Ankieta własnej konstrukcji obejmowała 45 rozbudowanych pytań różnego typu (zamkniętych i otwartych), dotyczących przedmiotu badan, oraz metryczkę obejmującą 14 pytań. Merytoryczna część ankiety zawierała pytania dotyczące wspomagania rozwoju dziecka z uszkodzonym słuchem przez ich ojców słyszących, sposobu postrzegania przez nich swojego niesłyszącego dziecka, rozumienia swojej roli jako ojca dziecka niesłyszącego oraz własnej oceny siebie jako ojca takiego dziecka.

W badaniach wzięła udział grupa 14 ojców w wieku 35-46 lat zamieszkałych w Lublinie, Biłgoraju i Siedlcach oraz okolicach. Nie jest to grupa duża. Niestety wielu ojców odmawiało udziału, tłumacząc się brakiem czasu, niechęcią do pisania lub odpowiadania na pytania ankiety. Połowa respondentów pochodziła $\mathrm{z}$ miasta - czterech z miasta do 50 tys. i trzech z miasta powyżej 50 tys. mieszkańców, natomiast pozostałych 7 ojców mieszkało na wsi. Wszystkie rodziny, które tworzyli, były pełne. W relacji ojców ich stosunek do żony po diagnozie niepełnosprawności dziecka nie zmienił się. Dzieci respondentów były w przedziale wiekowym 4-15 lat, wśród nich była tylko jedna dziewczynka. Oprócz jednego dziecka wszystkie inne miały słyszące rodzeństwo (siedmioro - jedno; pięcioro - dwoje; jedno miało troje rodzeństwa). Dzieci charakteryzowały się dwoma rodzajami uszkodzenia narządu słuchu - typu przewodzeniowego (pięcioro dzieci) i odbiorczego (dziewięcioro dzieci). Oprócz dwójki dzieci, u pozostałych czas wystąpienia wady był na etapie prelingwalnym, a stopień uszkodzenia był u pięciorga dzieci głęboki, u sześciorga - znaczny, natomiast u trojga - umiarkowany. Większość dzieci wymagała więc protezowania i rehabilitacji, gdyż komunikacja $\mathrm{z}$ otoczeniem mogła być poważnie zaburzona. Tylko jedno dziecko nie korzystało z pomocy logopedy i tylko jedno nie nosiło aparatu słuchowego.

\footnotetext{
${ }^{2}$ Obecnie: Katarzyna Tupaj.

${ }^{3}$ Wstępnie planowano przeprowadzenie wywiadów z ojcami dzieci z uszkodzeniem słuchu, jednak okazało się, że niezmiernie trudno jest dotrzeć do ojców, a potem uzyskać od nich zgodę na przeprowadzenie dłuższej osobistej rozmowy. Dlatego pytania wywiadu przepracowano w pytania ankiety, którą ojcowie wypełniali sami.
} 
Dzieci chodziły głównie do szkoły masowej (5) lub specjalnej (5), troje do integracyjnej, a jedno do szkoły niepublicznej ${ }^{4}$.

\section{WSPOMAGANIE PRZEZ BADANYCH OJCÓW ROZWOJU DZIECKA Z USZKODZONYM SŁUCHEM}

Wspomaganie przez ojców rozwoju dziecka może mieć różne formy. Jedną z nich jest dyspozycyjność do prowadzenia rozmowy, kiedy ono tego potrzebuje. Tylko jeden ojciec przyznał, że zazwyczaj nie ma na to ochoty, a dwóch określiło swoją postawę jako ambiwalentną. Pozostali chętnie (4) lub zdecydowanie chętnie (7) podejmują rozmowę. Najczęściej poruszane tematy to sprawy życia codziennego, hobby, problemy dziecka, a także rozmowy o szkole i kolegach. Ojcowie, którzy niechętnie odnosili się do rozmowy z dzieckiem, rzeczywiście rzadko podejmowali konwersację z nim. Dotyczyło to trzech ojców. Pozostali rozmawiali z dzieckiem często (5), a nawet bardzo często (6). Większość ojców (10) przyznała, że tłumaczy dziecku, jak ma postępować w różnych sytuacjach, co jest dobre, a co złe. Tylko trzech stwierdziło, że zazwyczaj tego nie robią. Wynik ten wskazuje na świadomość wychowawczą ojców i ich zaangażowanie we wprowadzanie dziecka w świat wartości, które będą dla niego ważne na całe życie.

Ze względu na dominującą rolę matki w wychowaniu dziecka niesłyszącego zapytano ojców o ich potrzebę zaangażowania się w proces wspomagania dziecka w rozwoju. Połowa ojców była przekonana, że to matka powinna wspierać rozwój, trzech było niezdecydowanych co do swej roli w tym zakresie, a tylko czterech przyznało, że jest to również ich zadanie (tylko dwóch było zdecydowanie do tego przekonanych). Pomimo takiej opinii co do optymalnej ich zdaniem sytuacji, ośmiu ojców przyznało, że uczestniczą aktywnie w wychowaniu dziecka w tym samym stopniu co żona (ale tylko trzech z nich uważało, że zdecydowanie są tak samo zaangażowani), a czterech czasem włączało się na równi z matką. O ile więc większość respondentów

\footnotetext{
${ }^{4}$ Ze względu na długość ankiety pominięto w pytaniach szczegółowe kwestie opisujące grupę dzieci, których ojcowie byli badani, np. jak komunikują się one z otoczeniem, jak funkcjonują pod względem społecznym, dlaczego korzystają/nie korzystają z zajęć logopedycznych, noszą lub nie noszą aparatów, od kiedy mają problemy ze słuchem? Zdobycie jednolitej pod wieloma względami grupy dzieci, których ojcowie chcieliby odpowiedzieć na długą ankietę, okazało się niemożliwe dla autorek, które nie pracują w placówce zajmującej się dziećmi niesłyszącymi i mogły jedynie zdobywać dostęp do ojca dziecka niesłyszącego poprzez kontakt z nim w szkole, do której dziecko uczęszcza.
} 
uczestniczy we wspieraniu swojego dziecka w rozwoju poprzez thumaczenie $\mathrm{mu}$, co jest dobre, a co złe, to jednak zdaniem połowy to raczej żona powinna zajmować się emocjonalnym wspieraniem dziecka. Widać wyraźnie, że w tej roli, jaką jest dostarczanie dziecku wsparcia uczuciowego, ojcowie nie czują się najlepiej i delegują do tego swoje żony.

Co do obecności ojców w wydarzeniach związanych z dzieckiem połowa z nich uczestniczyła często (4) lub bardzo często (3), pięciu czasem, a dwóch rzadko. Jednak tylko trzech ojców zawsze, a dwóch często uczestniczyło w wywiadówkach, natomiast pozostali czynili to czasem (2) lub rzadko (2), a czterech nigdy nie brało w nich udziału ${ }^{5}$. Czynności, w których ojcowie uczestniczyli codziennie, to: spędzanie wspólnie wolnego czasu i odmawianie modlitwy (3), odprowadzanie dziecka do lub ze szkoły, odrabianie lekcji, wspólna zabawa, pomoc w toalecie i garderobie (2). Czynności, w których ojcowie uczestniczyli często, to: pomoc w toalecie i garderobie (9), chodzenie z dzieckiem do kościoła (6), odprowadzanie do lub ze szkoły i wspólne spędzanie czasu (po 5 ojców), odrabianie lekcji i prowadzenie na zajęcia dodatkowe (po 4 ojców), sprzątanie (3), zabawa i przygotowanie posiłków (po 2 ojców), odmawianie modlitwy (1). Można więc zauważyć, że aktywność ojców w codziennych czynnościach związanych z dzieckiem nie jest duża, ale są ojcowie szczególnie zaangażowani w obowiązki rodzicielskie.

U dziecka niesłyszącego edukacja obejmuje nie tylko naukę szkolną, ale również codzienną naukę związaną z mową, pisaniem, czytaniem i zasadami funkcjonowania w różnych sytuacjach społecznych. Pomoc rodziców w procesie edukacji dziecka wymaga od nich dużego nakładu czasu i energii, cierpliwości i zaangażowania. Większość ojców relacjonowała swój udział we wspieraniu dziecka w nauce mówienia, czytania i pisania, a także zainteresowanie szukaniem informacji na temat niepełnosprawności, aby lepiej poznać dziecięce potrzeby. Najczęściej ojcowie wspomagali dziecko w związku z jego uczestnictwem w edukacji szkolnej (pięciu ojców codziennie i tyleż kilka razy w tygodniu), w zajęciach surdologopedycznych (ośmiu kilka razy w miesiącu, zaś pięciu nigdy). Akurat te zajęcia to nieodłączny element życia niesłyszącego dziecka, związany z wysiłkiem nauki mowy, dlatego wsparcie ze strony obojga rodziców jest dla dziecka bardzo ważne. Pomocy dziecku w dodatkowych zajęciach pozalekcyjnych udzielało kilka razy w tygodniu dwóch ojców, kilka razy w miesiącu - pięciu, kilka razy w roku trzech i tyleż - nigdy. Ojcowie starali się wspomagać dziecko, jednak ich

\footnotetext{
${ }^{5}$ Jeden ojciec nie udzielił odpowiedzi na to pytanie. Ojcowie dzieci słyszących również nie są często obecni na wywiadówkach, więc wynik ten jest podobny dla ojców obu grup.
} 
udział nie był równy udziałowi matek, co może wynikać z ich zaangażowania $\mathrm{w}$ pracę zawodową. Podobnie więc i w tym wypadku rola matki we wspomaganiu dziecka niesłyszącego w różnych pozaszkolnych formach edukacji jest większa niż wkład ojca.

Otrzymane wyniki badań są częściowo podobne do tych, jakie uzyskała M. Klaczak (1996, s. 207), gdyż z jej badań również wynikało, że osobą szczególnie zajmującą się pracą rewalidacyjną z dzieckiem była matka $(86,2 \%)$. Tylko ośmiu ojców, co stanowiło 13,8\% grupy, poświęcało pracy z dzieckiem tyle samo czasu co matka, jednak był to głównie czas przeznaczony na zabawę i rozmowy, mniej na ćwiczenia słuchowe. Wyniki referowanych tu badań własnych są bardziej optymistyczne, ale może wynikać to z kilku przyczyn: zwiększenia na przestrzeni lat udziału ojców w rewalidacji swoich dzieci, specyficznej grupy badanej, którą byli ojcowie przywożący swoje dziecko do ośrodka edukacyjnego, a więc zaangażowani w opiekę nad nim lub też $\mathrm{z}$ ich chęci pokazania się $\mathrm{w}$ dobrym świetle $\mathrm{w}$ trakcie odpowiadania na pytania ankiety.

W rozwoju dziecka niesłyszącego niezbędne jest ćwiczenie jego umiejętności mówienia, czytania i pisania. Czynności te przychodzą dziecku z uszkodzonym słuchem dużo trudniej niż dzieciom słyszącym. Bardzo często wada słuchu nie pozwala opanować tych umiejętności w pełni. Wsparcie rodziców jest niezbędne, aby dziecko nie rezygnowało $z$ wysiłków związanych z nauką poprawnej wymowy. Z referowanych badań własnych wynika, że jedenastu ojców uczestniczyło w nauce mowy dziecka, wykonywali z nim ćwiczenia (10), włączali się w naukę czytania (10) i pisania (9).

Pozytywny wpływ na rozwój każdego dziecka ma aktywny i kreatywny sposób spędzania czasu w domu. Ojcowie dzieci niesłyszących szczególnie dbali, aby miało ono możliwość rozwoju osobistego poprzez: granie z nim w gry planszowe (10), zachęcanie do czytania książek (9), wykonywania prac plastycznych (8) i oglądania filmów edukacyjnych, recytacji wierszy i śpiewania piosenek (po 4). Ojcowie raczej unikali działań aktywizujących, które wymagałyby ich większego wkładu własnego, ich zaangażowania i kreatywności. W większości proponowali dzieciom czynności, w których cały udział jest dziecka, a ojciec z boku czuwa i ocenia postępy.

Wspomaganie dziecka wymaga również podjęcia przez ojca poszerzania wiedzy na temat niepełnosprawności dziecka, aby mógł lepiej zrozumieć jego potrzeby i wyjść im naprzeciw. Jednym ze sposobów przyswojenia informacji o potrzebach niesłyszącego dziecka jest nawiązanie kontaktów z osobami ze środowiska osób niesłyszących. Tylko czterech ojców nawiązało kontakt 
ze środowiskiem osób niesłyszących, trzech wysyłało dziecko na turnusy rehabilitacyjne, a dwóch starało się zapewnić dziecku kontakt z niesłyszącymi. Być może ojcowie nie starali się włączać swoich dzieci do środowiska niesłyszących, gdyż chcą im zapewnić jak najlepsze warunki do integracji społecznej, a efekty wczesnego wspomagania i wyposażenia w aparat słuchowy pozwalają mieć nadzieję na pełną inkluzję. Niektórym dzieciom jednak takie kontakty $\mathrm{z}$ innymi niesłyszącymi (w większości korzystającymi z aparatów słuchowych lub implantów) mogłyby być pomocne, gdyż trwałe przyjaźnie z lat dzieciństwa mogą być wsparciem w zmaganiu się z problemami dorosłości.

Bardzo ważne dla poprawnego rozwoju dziecka jest, aby rodzice zdawali sobie sprawę z tego, na czym polega niepełnosprawność dziecka i jak z nim postępować. Interesujący jest fakt, wynikły z badań, że dla $2 / 3$ badanych ojców głównym źródłem wiedzy o głuchocie był lekarz oraz Internet (10), a następnie żona (9), poradnie psychologiczno-pedagogiczne (8), rehabilitanci/terapeuci (6) i książki specjalistyczne (5).

Aby wspomagać rozwój dziecka, konieczna jest kompetencja komunikacyjna. W większości jedno z rodziców opanowuje znaną dziecku metodę komunikacji z innymi, ale wtedy drugi zostaje wycofany z kontaktu. Najwięcej ojców korzystało w przeszłości z metod audytywno-werbalnych (6), zaś obecnie korzysta z metod oralnych (5) i z komunikacji totalnej (5). Najmniejszym zainteresowaniem wyróżniały się takie metody, jak bilingwizm i Polski Język Migowy - sześciu ojców stwierdziło, że nie korzystało nigdy z tych metod. Tylko jeden ojciec posługiwał się fonogestami i jeden znał tę metodę, pozostali nie znali i nie korzystali z niej. Aż dwunastu ojców stwierdziło, że decyzja o nauczeniu się metody komunikacji językowej z dzieckiem była ich samodzielną decyzją, ale tylko jeden ojciec uczestniczył w specjalnym kursie konkretnej metody komunikacji z dzieckiem, jaką jest język migowy. Pozostali starali się komunikować z dzieckiem bez specjalnego szkolenia.

\section{PRZEŻYCIA OJCA ZWIĄZANE Z DIAGNOZĄ \\ O USZKODZENIU SŁUCHU U DZIECKA}

Jednym z ważnych wyznaczników stosunku ojca do dziecka z niepełnosprawnością są jego emocje po uzyskaniu diagnozy o wadzie słuchu. Do najczęściej doświadczanych uczuć po otrzymaniu niepomyślnej diagnozy rozwojowej należały: smutek (8), lęk przed przyszłością (7), bezradność (6) i żal (4). Szok, złość i poczucie niesprawiedliwości było wskazywanych tyl- 
ko przez trzy osoby, niedowierzanie i obojętność przez dwie, wyrzuty sumienia, poczucie krzywdy i poczucie niewiary w Boga przez jedną osobę. Żaden z mężczyzn nie doświadczył przeżycia załamania psychicznego, poczucia bezsensu, fiaska swoich planów życiowych, ale też nikt nie wskazał na uczucie nadziei. Po uzyskaniu diagnozy o niepełnosprawności dziecka może pojawić się tendencja do szukania winnych za to, co się wydarzyło. Żaden z respondentów nie obwiniał żony lub dziecka za niedosłuch, jeden obwiniał siebie, natomiast winą obciążali lekarzy i placówki medyczne (6) oraz Boga (4). Niektóre otrzymane wyniki ankiety są niespójne, np. ich zdaniem nie doświadczali załamania planów życiowych, a jednocześnie przyznawali się do lęku o przyszłość i do braku nadziei.

Trudne sytuacje często powodują, że człowiek zaczyna odczuwać bezsilność i nie zawsze radzi sobie z ciężarem obowiązków. Podobnie jest w sytuacji wychowywania dziecka $\mathrm{z}$ niepełnosprawnością. Bycie rodzicem dziecka dalekiego od swoich wymarzonych ideałów, to dla niektórych ojców „ojcostwo niepełne". Nie mogą robić z dzieckiem tego, co sprawiłoby, że mogliby być z niego dumni, że mogliby się nim pochwalić. Ich ojcostwo jest „ograniczone" przez niepełnosprawność dziecka. Dodatkowo, dochodzą nowe obowiązki i wiele wymagań ze strony żony. Czasami, gdy człowiek jest w przytłaczającej sytuacji, poszukuje różnych sposobów rozluźnienia, które bardzo często negatywnie wpływają na relacje rodzinne. Interesującym wynikiem obecnych badań było uzyskanie zaprzeczenia od 11 na 14 ojców na pytanie o to, czy czując przeciążenie z powodu posiadania i wychowywania dziecka z niepełnosprawnością, uciekał się do rozluźnienia poprzez, np.: spożycie alkoholu, rozładowanie emocji na innych, gry komputerowe, programy w TV, spotkania z kolegami, spotkania z kobietami, używki. Tylko trzech ojców przyznało, że zdarzało się im w ten sposób radzić sobie ze stresem powstałej sytuacji rodzinnej ${ }^{6}$.

\section{SPOSÓB POSTRZEGANIA DZIECKA NIESŁYSZĄCEGO PRZEZ JEGO OJCA}

Ojcowie, którzy wzięli udział w badaniach, zaprzeczali przeżywaniu negatywnych uczuć wobec swojego niesłyszącego dziecka. Na pytanie, czy zdarza się ojcu odczuwać negatywne emocje wobec dziecka (np. złość, nie-

\footnotetext{
${ }^{6}$ Por. J. Kobosko (2013b). Na podstawie badań słyszących ojców dzieci głuchych autorka stwierdziła, że nie występują istotne różnice między ojcami dzieci głuchych i słyszących w stosowanych stylach radzenia sobie ze stresem.
} 
cierpliwość), tylko jeden $\mathrm{z}$ nich odpowiedział twierdząco, pozostali stwierdzili, że emocje takie pojawiają się rzadko (5), a nawet bardzo rzadko (8). W pytaniu o poczucie dumy z dziecka tylko dwóch ojców odpowiedziało „, tak, i nie”, pozostali ojcowie są zwykle dumni (7) lub zdecydowanie czują dumę z dziecka (5). Powodem dumy było przede wszystkim to, że jest ono silne i cierpliwe oraz że potrafi zarazić innych swoją miłością, a także to, że jest zdolne, inteligentne, samodzielne, osiąga sukcesy sportowe, dobrze radzi sobie w życiu. Tylko trzech ojców uważało, że inteligencja dziecka jest obniżona, natomiast jedenastu ojców było przekonanych, że ich dziecko jest tak samo inteligentne jak inne dzieci. Ojcowie mieli nadzieję na pomyślną przyszłość swojego dziecka. Wszyscy wierzyli, że ukończy ono szkołę, będzie zupełnie samodzielne i założy rodzinę, dwunastu ojców było przekonanych, że zdobędzie ono kwalifikacje odpowiednie do podjęcia pracy, jedenastu ojców wierzyło, że dziecko osiągnie sukces zawodowy, a dziesięciu wspomniało o sukcesie sportowym. Połowa grupy ojców była przekonana, że dziecko zdobędzie wyższe wykształcenie. Do niezależności życiowej przygotowuje dziecko postawa ojca - dwunastu z nich było zdania, że nie należy wyręczać dziecka w sytuacjach, które są dla niego trudne.

Podejście oraz nastawienie ojca do dziecka ma bardzo duży wpływ na samoocenę dziecka. Zapytano więc ojców, czy w ich opinii dziecko z uszkodzonym słuchem funkcjonuje gorzej od innych dzieci - tylko jeden ojciec odpowiedział twierdząco, połowa uważała, że nie ma różnic, a sześciu było niezdecydowanych, podkreślając, że można mówić o słabszych wynikach w zakresie mowy, nauki języków obcych, ogólnie w nauce oraz w zakresie uzdolnień muzycznych. Wszyscy ojcowie stwierdzali, że nie wstydzą się swojego dziecka i wychodzą z nim do miejsc publicznych i prawie żaden nie bał się reakcji innych wobec dziecka niesłyszącego (13).

Podsumowując wyniki tej części badań, można stwierdzić, że większość ojców nie odczuwała negatywnych uczuć do swojego dziecka. W większości nie uważali, że dziecko jest mniej inteligentne lub gorsze od rówieśników oraz nie wstydzili się jego niepełnosprawności. Byli realistami i zdawali sobie sprawę, że dziecko może czasem wypaść gorzej na tle grupy z powodu swoich trudności słuchowych. Mieli jednak nadzieję, że dzięki zaradności i samodzielności odniesie ono w przyszłości sukces życiowy.

Kolejnym interesującym aspektem jest to, jak ojcowie postrzegają umiejętności swoich dzieci z uszkodzonym słuchem, na ile są w stanie ocenić rzeczywisty poziom kompetencji dziecka w czytaniu, pisaniu i mówieniu, bez zbytniej surowości, ale też pobłażliwości. 


\section{OJCOSTWO WOBEC DZIECKA NIESŁYSZĄCEGO W ROZUMIENIU OJCÓW SŁYSZĄCYCH}

Ojcostwo $\mathrm{w}$ rozumieniu respondentów łączy się z miłością, zrozumieniem, pomocą, opieką, troską, wiarą i nadzieją. W ich opinii ojcostwo to wychowanie $\mathrm{w}$ duchu rodzinnym i chrześcijańskim oraz odpowiedzialność za drugiego człowieka. To również wspieranie rozwoju dziecka, pomoc w trudnych dla niego sytuacjach i zapewnienie bytu materialnego rodzinie. Ojciec powinien być ich zdaniem nauczycielem, przewodnikiem, przyjacielem, opiekunem i kumplem.

Zapytano respondentów, czy uważają, że ojcostwo wobec dziecka niesłyszącego różni się od ojcostwa wobec dziecka słyszącego. Większość badanych ojców miała więcej niż jedno dziecko, mieli więc możliwość porównania w tym zakresie. Charakteryzując swoje podejście do dziecka niesłyszącego, 2/3 ojców (9) stwierdziło, że nie ma różnicy, jest ono bowiem takie samo jak do innych dzieci. Natomiast pozostali uważali, że wychowywanie dziecka niedosłyszącego różni się, gdyż wymaga ono większej uwagi, pomocy i cierpliwości ze strony rodziców, tłumaczenia wszystkiego w bardziej dokładny, prosty i zrozumiały dla niego sposób oraz częstszej i regularnej opieki medycznej. Niektórzy podkreślili, że do dziecka niesłyszącego mają więcej miłości, podejmują więcej działań opiekuńczych, wspierają je, starają się nie dać dziecku odczuć, że jest „inne”. Jeden z ojców stwierdził dobitnie, że wychowywanie dziecka niedosłyszącego wiąże się z większą liczbą obowiązków i większą odpowiedzialnością za rodzinę ze strony ojca. Z relacji ojców wynika, że czują się zaangażowani w wychowanie i często poświęcają pewne sprawy na rzecz bycia z dzieckiem (np. możliwość lepszego stanowiska pracy).

Na pytanie o łatwość kontaktu z dzieckiem, pomimo obiektywnych trudności związanych z rozumieniem jego mowy (nie mówi zbyt wyraźnie, posługuje się gestami), zdecydowana większość ojców odpowiedziała twierdząco (6 - zdecydowanie łatwo, 5 - raczej łatwo). Trzech ojców przyznało, że czasami mają w tym zakresie kłopoty. W większości rozumieli, co dziecko do nich mówi i czego od nich chce. Tylko jeden ojciec przyznał, że czasami nie rozumie, czego dziecko oczekuje od niego i o co go prosi. 


\section{OCENA WŁASNEGO OJCOSTWA \\ PRZEZ OJCÓW DZIECI Z USZKODZONYM SŁUCHEM}

To, jak ojcowie postrzegają siebie oraz jak widzą siebie w oczach innych, ma duży wpływ na ich postawy wobec dziecka i rodziny. Jeśli mężczyzna odczuwa, że jest postrzegany pozytywnie, ma chęć bliskiego kontaktu z członkami rodziny i obdzielania ich swoimi pozytywnymi uczuciami. Wyniki badań grupy ojców dziecka $\mathrm{z}$ uszkodzeniem słuchu wskazują na zgodność obrazu ich ojcostwa relacjonowanego przez nich samych oraz $\mathrm{w}$ ich ocenie przez ich żony i dzieci.

W odpowiedzi na pytanie „Jakim jest Pan ojcem według Pańskiej żony?” 11 na 14 ojców uważało, że żony są zadowolone z ich ojcowskiej roli i zaangażowania - zdaniem połowy mężczyzn są oni w oczach żon dobrymi ojcami, a zdaniem czterech - nawet bardzo dobrymi ojcami. Dwóch mężów oceniło, że żony uważają ich za przeciętnych ojców, a tylko jeden przyznał, że żona uważa, że jest złym ojcem. Podobne wyniki uzyskano w odpowiedzi na pytanie „Jakim jest Pan ojcem według Pana dziecka niesłyszącego?”. Tylko jeden ojciec stwierdził, że dziecko bardzo źle ocenia jakość jego ojcostwa. Dwóch ojców stwierdziło, że w oczach dzieci są przeciętnymi ojcami, natomiast pozostali (11) wyrazili przekonanie o pozytywnym wizerunku swojego ojcostwa u swoich dzieci (,dobry ojciec” - 5, „bardzo dobry ojciec" -6 ).

Powyższe wyniki dotyczące obrazu ojcostwa u żon i dzieci w rodzinie z dzieckiem niesłyszącym są zbliżone do tego, jak ojcowie sami oceniali swoje ojcostwo. Na pytanie „Jakim jest Pan ojcem w swojej własnej, szczerej ocenie?" żaden ojciec nie ocenił siebie jako bardzo złego, jeden określił się jako „zły” (ten sam, którego zdaniem i żona, i dziecko ocenia go jako złego ojca i nieraz o tym słyszy), trzech określiło się jako „przeciętny”, pozostałych dziesięciu ma bardziej pozytywną wizję siebie jako ojca („dobry” - 8; „bardzo dobry” - 2). Odpowiedzi te korespondują z oceną stopnia zadowolenia ze swojej postawy wobec dziecka niesłyszącego. Okazało się, że dwunastu respondentów było zadowolonych ze swojej postawy rodzicielskiej (,zazwyczaj” - 9; ,zdecydowanie tak”-3). Tylko dwóm ojcom trudno było określić stopień satysfakcji z tej sfery (,,i tak, i nie”).

J. Kobosko (2013) w swoich badaniach uzyskała wyniki wskazujące na podobną samoocenę siebie jako ojca w grupie słyszących ojców dzieci niesłyszących, co może wynikać m.in. z mechanizmu obronnego zaprzeczania przeżyciom związanym z głuchotą dziecka, aby chronić się przed cierpieniem. 
Podobny wynik stosunkowo wysokiej samooceny roli ojcowskiej u mężczyzn posiadających dziecko niepełnosprawne intelektualnie w porównaniu z ojcami dzieci sprawnych uzyskała Karwowska (2009). Mężczyźni wychowujący dziecko z zespołem Downa oceniali nawet lepiej swoje ojcostwo niż ojcowie dzieci sprawnych. Jednak zauważono, że przejawiali oni skłonność do zawyżania samooceny ojcostwa w zakresie aspektu intelektualnego, wolicjonalno-emocjonalnego i wychowawczego, natomiast zaniżali samoocenę w zakresie aspektu opiekuńczego i rehabilitacyjnego, gdyż ze względu na swoje obowiązki ekonomicznego zabezpieczenia rodziny oraz stereotyp matki-opiekunki, nie mieli warunków do realizacji tych funkcji na równi z żonami czy też na miarę swoich potrzeb.

\section{POSTAWY OJCÓW WEDŁUG KWESTIONARIUSZA DLA RODZICÓW MARII ZIEMSKIEJ}

Kwestionariusz dla Rodziców Marii Ziemskiej służy do diagnozy postaw rodzicielskich. Przy jego pomocy można określić natężenie czterech postaw, które są niekorzystne dla rozwoju dziecka: bezradność, dystans, górowanie i nadmierna koncentracja (1973, s. 33). Analizując wszystkie odpowiedzi na twierdzenia zawarte w Kwestionariuszu dla Rodziców, można zauważyć, że za najbardziej słuszne najwięcej ojców uznało takie twierdzenia, jak: „Jeżeli rodzice zauważą, że to oni się mylą, a dziecko ma słuszność, powinni przyznać mu rację” (10 ojców), „Dziecko należy nauczyć unikania bójek ze względu na ich skutek” (9), „Dziecko ma prawo do swojego punktu widzenia i wypowiadania go” (8), „Jeśli jest się dość stanowczym, dzieci nie wejdą na głowę" (7). Prawie połowa badanych ojców (6) uznała za zdecydowanie prawdziwe stwierdzenia: „Spędzanie z dzieckiem czasu po pracy to dobry odpoczynek”, „Jeśli stawiamy dziecku wymagania i okazujemy zadowolenie z ich spełnienia, ono staje się posłuszne”, „Dziecku można pozwolić na posiadanie własnych tajemnic i sekretów". Natomiast za zdecydowanie błędne najwięcej ojców uznało następujące twierdzenia: „Dbałość o dziecko wymaga dawania mu drogich owoców i różnych drogich rzeczy” (12), „Nawet małym dzieciom można pozwolić bawić się na bocznych uliczkach bez nadzoru” (9), „Dawanie dzieciom rad i wskazówek jest stratą czasu, bo dzieci albo ich nie słuchają, albo nie potrzebują” (8), „Jeśli dziecko na chwilę spuści się z oczu, będą kłopoty” (6) oraz „Dzieciom można zostawić swobodę przychodzenia i wychodzenia z domu bez opowiadania się" (6). 
Zestawienie wyników wszystkich badanych ojców daje średnią, która wskazuje na to, że postawy: górowania, bezradności, koncentracji i dystansu nie mają niepokojącego natężenia, tzn. pozostają $w$ granicach średnich. W przeliczeniu na steny, średnia wynosi dla górowania 5,1, dla bezradności 5,6, dla dystansu 6,0, dla koncentracji 6,1. Respondenci mają więc nieco większą tendencję do przyjmowania postawy nadmiernej koncentracji wobec dziecka niż postawy górowania wobec niego, ale nasilenie negatywnych postaw obliczane dla całej grupy nie wskazuje na ich patologię.

Bardziej dogłębne przyjrzenie się natężeniu każdej z postaw u konkretnych osób ujawnia jednak rozbieżności w wynikach, np. trzech ojców uzyskało wynik przekraczający normę w zakresie postawy górowania (dwóch osiągnęło sten 7 i jeden - sten 8). W odniesieniu do postawy bezradności uzyskano wyniki powyżej średniej u czterech ojców, w tym dwóch z nich uzyskało niepokojąco wysokie natężenie postawy bezradności, otrzymując wynik 8 i 9 stenów. Postawę nadmiernej koncentracji na dziecku przyjmowało pięciu ojców, w tym dwóch miało wysokie wyniki - 8 i 10 stenów. Największym problemem wychowawczym okazała się postawa nadmiernego dystansu wobec dziecka. Aż połowa badanych ojców przyjmowała postawę nadmiernego dystansu, a wśród nich trzech uzyskało wynik o wartości 8 stenów oraz jeden ojciec - wynik 9 stenów. Szczegółowe wyniki otrzymane przez konkretnych ojców w zakresie przyjmowanych postaw rodzicielskich wskazują na problemy, z jakimi borykają się oni w relacjach z dzieckiem, a które mogą mieć niesprzyjający wpływ na rozwój jego osobowości oraz relacje z innymi ludźmi.

O współzależności między błędnymi postawami rodzicielskimi a reakcjami nerwicowymi ich niesłyszących dzieci pisali już 50 lat temu na podstawie przeprowadzonych przez siebie badań empirycznych T. Gałkowski, J. Grossman i B. Skórzak (1966). Rodzice dzieci niesłyszących skarżą się na objawy nerwicowe, trudności zachowania równowagi emocjonalnej, co zostało potwierdzone w badaniach Inwentarzem Osobowości H.J. Eysencka, w których u 50\% badanych rodziców stwierdzono wysoką lub bardzo wysoką neurotyczność (Gałkowski, Kunicka- Kaiser, Smoleńska, 1976, s. 169-175), objawy niepokoju, bezsenności i depresji (Kobosko, 2013, 2014), co ma wpływ na kształtowanie się osobowości ich dzieci (Trębicka-Postrzygacz, 1999; Kobosko, 2009, 2011; Marcinkowska, 2009, s. 30-31). Podobne badania prowadzone za granicą wskazują na nasilenie stresu i trudności w radzeniu 
sobie z nim u ojców dzieci niesłyszących (np. Åsberg, Vogel, Bowers, 2008; Zaidman-Zait i in., 2016) ${ }^{7}$.

Podsumowując uzyskane wyniki badań, można stwierdzić, że większość badanych ojców zachowuje odpowiednią postawę wobec swojego dziecka, ale wartości stenowe ujawniają trudności, gdyż nawet jeśli wyniki średnie wskazują na normę, to wszystkie średnie czterech postaw są powyżej 5,0, a więc oscylują w kierunku postaw negatywnych. Kilku ojców przyjmowało postawę nadmiernej bezradności i górowania nad dzieckiem oraz koncentracji na nim. Najbardziej niepokojącym wynikiem było to, że aż u połowy ojców stwierdzono postawę nadmiernego dystansu, co może wpływać negatywnie na rozwój ich niepełnosprawnego dziecka. Przyczyną tej postawy może być duże zaangażowanie zawodowe ojca i brak czasu na bliższe kontakty z dzieckiem lub trudności w komunikacji z nim.

\section{PODSUMOWANIE WYNIKÓW BADAŃ}

Z referowanych wyników badań empirycznych nad wypełnianiem przez ojców słyszących roli wychowawczej i wspomagającej swoje niesłyszące dziecko wypływa kilka wniosków. Zgodnie z tym, jak ojcowie prezentowali swoją postawę wobec dziecka i rolę w zakresie wspomagania go w rozwoju, można stwierdzić: 1. Ojcowie rozumieją ojcostwo jako odpowiedzialność za dziecko i obowiązek zaspokojenia jego potrzeby bezpieczeństwa oraz potrzeb dotyczących sfery fizycznej, materialnej oraz psychicznej (poznawczej i emocjonalnej); 2. Ojcowie oceniają siebie jako dobrych ojców dziecka z uszkodzonym słuchem; 3. Ojcowie w większości starają się wspomagać rozwój swojego dziecka poprzez uczestniczenie w jego codziennych czynnościach, w rehabilitacji, w ważnych wydarzeniach życiowych i wpajaniu hierarchii wartości, ale żonie przypisują znacznie większą rolę w codziennym życiu dziecka oraz we wspieraniu go emocjonalnym; 4. Ojcowie postrzegają swoje dziecko niedosłyszące jako samodzielne, jednak potrzebujące więcej opieki i troski niż dziecko słyszące; 5. Ojcowie mają pozytywną wizję przyszłości swojego niesłyszącego dziecka, uważają, że da ono sobie radę w życiu. 6. Ojcowie dziecka $\mathrm{z}$ uszkodzonym słuchem różnią się $\mathrm{w}$ zakresie postaw

${ }^{7} \mathrm{Z}$ szerszą literaturą na ten temat może czytelnik zapoznać się w artykule znajdującym się również w tym numerze Roczników Pedagogicznych: D. Kornas-Biela, „Ojcostwo mężczyzn wychowujących dzieci z uszkodzonym słuchem. Część I". 
rodzicielskich. Niektórzy przyjmują postawę nadmiernego górowania, kontrolowania i bezradności, połowa z nich charakteryzuje się postawą dystansu.

Wyniki wskazujące na pozytywną wizję własnego ojcostwa badanych ojców można odnieść do literatury przedmiotu, w której podkreśla się, że rodzicielstwo dziecka niesłyszącego, oprócz trudnych wyzwań może nieść również pozytywne doświadczenia, które stymulują do wglądu w priorytety rodzinne, wyznaczenia nowych celów w życiu, zbliżenia się do siebie członków rodziny, akceptacji każdego członka rodziny takim, jaki jest. Akceptacja dziecka i jego niepełnosprawności jest pozytywnym „etapem” dostosowania się rodziny do zaistniałej sytuacji (Blacher, 1984, za: Zaidman-Zait i in., 2016).

W obecnych badaniach nie było możliwości sprawdzenia, na ile oceny dokonywane przez ojców odnośnie do swojej ojcowskiej roli są rzeczywiście zgodne z rzeczywistością, ale fakt, że ojcowie stali się respondentami właśnie dlatego, że przyprowadzali dziecko do szkoły, świadczy o tym, że biorą udział w jego wychowaniu. Ciągle interesującym problemem pozostają różne aspekty roli ojca słyszącego w życiu dziecka z uszkodzonym słuchem, a zwłaszcza jego percepcja własnej roli i postaw wobec dziecka, jego wizja obowiązków wychowawczych i zaangażowania w ich realizację oraz zgodność tej oceny z rzeczywistą oceną dokonaną przez jego żonę i dzieci. Interesujące byłoby oczywiście zbadanie czynników, które mają wpływ na spełnianie przez ojca dziecka niesłyszącego roli rodzicielskiej, oraz tych, które mają wpływ na ocenę tej roli (np. przeszacowanie lub niedoszacowanie). Jest to szersze zagadnienie, które może być przedmiotem dalszych badań. Ponadto, przyszłe badania powinny objąć większą próbę badanych osób, uwzględniając w jej doborze różne zmienne. Ciekawym terenem badawczym byłoby uchwycenie wpływu, np. cech osobowościowych ojca, jego funkcjonowania $w$ roli rodzicielskiej, jego postaw wobec dziecka, jego relacji z żoną na rozwój języka dziecka, jego psychikę, osiągnięcia edukacyjne i przyszłą drogę życiową.

Niezależnie od stosunkowo pozytywnej wizji własnego ojcostwa, wysokiej samooceny siebie jako ojca ${ }^{8}$, niektórzy ojcowie dzieci z różnym stopniem

${ }^{8}$ J. Kobosko pisze: „Niewykluczone, że dopiero badania jakościowe ojców dzieci głuchych dotyczące podjętych zagadnień, a także dotarcie do ojców 'nieobecnych' w badaniach (a więc w nich niereprezentowanych), pozwoliłyby na poznanie, jak ojcowie radzą sobie z głuchotą dziecka, a także czy ich 'podobieństwo' do ojców dzieci o typowym rozwoju wynika z obrony przed cierpieniem, adaptacji do głuchoty dziecka, niedoskonałości metodologicznych badań, czy jest odpowiedzią na potrzeby matek dzieci głuchych" (2013b, s. 43). Autorka zaznacza, że podobne wyniki osiągnięto w badaniach ojców dzieci z autyzmem i porażeniem mózgowym, dlatego nasuwa się pytanie, czy 
i rodzajem uszkodzenia słuchu oraz używania aparatów mogą potrzebować profesjonalnej pomocy, podobnie jak ich żony, rodzeństwo i dziadkowie dziecka z uszkodzeniem słuchu. Nie każdy członek rodziny będzie potrzebował profesjonalnej pomocy, ale każdy powinien mieć nie tylko taką możliwość, ale też być uświadomionym co do konieczności korzystania z różnorodnych form pomocy i wsparcia, jeśli zachodzi taka potrzeba, oraz być zmotywowanym, aby aktywnie ich poszukiwać. Szczególnej pomocy, jak wykazały otrzymane wyniki badań, wymagają ci ojcowie, u których nasilona jest postawa nadmiernych wymagań, dominacji i kontroli dziecka oraz mechanizmy obronne związane $\mathrm{z}$ doświadczaniem ukrywanego poczucia winy, lęków, bezradności, trudności w bezwarunkowej akceptacji dziecka. Korzystanie przez ojców/rodziców z usług pomocowych zwiększa ich zasoby osobiste i społeczne, a tym samym zmniejsza stres rodzicielski i poprawia funkcjonowanie dziecka niesłyszącego oraz jego rodzeństwa.

\section{BIBLIOGRAFIA}

Åsberg, K.K., Vogel, J.J., Bowers, C.A. (2008). Exploring correlates and predictors of stress in parents of children who are deaf: Implications of perceived social support and mode of communication. Journal of Child and Family Studies, 17(4), 486-499. DOI: 10.1007/s10826-0079169-7.

Bulicz, K. (2015). Postawy ojców słyszacych wobec wspomagania rozwoju ich dziecka z uszkodzonym stuchem. Praca magisterska, KUL, promotor: D. Kornas-Biela.

GaŁkowski, T. Kunicka-Kaiser, I., SMOleńska J. (1978). Psychologia dziecka głuchego. Warszawa: PWN.

GAŁKOWSKi, T., Grossman, J., SKÓRZAK, B. (1966). Réactions émotionelles des enfants infirmes et l'attitude des parents. Psychotherapy and Psychosomatics, 14, 180-185.

Gembal, A. (2001). Analiza postaw rodzicielskich ojców dzieci niestyszacych. Praca dyplomowa. Podyplomowe Studium Surdopedagogiki KUL, promotor: D. Kornas-Biela.

KARWOwSKa, M. (2009). Ojcostwo w samoocenie mężczyzn wychowujących dziecko niepełnosprawne. W: M. BIELSKA-ŁACH (red). Pedagogika specjalna: różne poszukiwania - wspólna misja (s. 359-371). Warszawa: Wydawnictwo Akademii Pedagogiki Specjalnej im. Marii Grzegorzewskiej.

KLACZAK, M. (1996). Rola rodziców dzieci z wadą słuchu w ich wczesnej rehabilitacji. W: R. OsSOWSKI (red.), Trudności w komunikowaniu się osób z uszkodzonym stuchem. Socjalizacja i rehabilitacja (s. 201-211). Bydgoszcz, Wyższa Szkoła Pedagogiczna w Bydgoszczy.

Koвosкo, J. (2009). Relacja matka - dziecko a zaburzenia rozwoju językowego u młodzieży głuchej. Przeglad Psychologiczny, 52(3), 327-342.

ojcowie dzieci głuchych (a także dzieci z inną niepełnosprawnością), którzy zgodzili się na udział w badaniach, są w jakiś sposób ojcami „szczególnymi”? (tamże, s. 42). 
Koвosko, J. (2011). Pomoc psychologiczna słyszącym rodzicom a efektywność rehabilitacji dzieci głuchych. Otorynolaryngologia, 10(1), 8-14.

Kовоsко, J. (2013). Depresja matek i ojców a głuchota dziecka. Znaczenie satysfakcji małżeńskiej jako predyktora nasilenia doświadczanych przez rodziców objawów depresji. Roczniki Pedagogiczne, 5(41), 3, 123-140.

Kовоsко, J. (2014). Problemy zdrowia psychicznego matek i ojców dzieci głuchych z implantem ślimakowym. Otolaryngologia Polska, 68(3), 135-142.

Kornas-Biela, D. (2001). Rodzice wobec diagnozy uszkodzenia słuchu u dziecka: doświadczenia rodziców, pomoc profesjonalistów. W: D. Kornas-Biela (red.), Rodzina: źródło życia i szkoła miłości (s. 459-477). Lublin: Towarzystwo Naukowe KUL.

Kornas-Biela, D. (2016). Rola ojca we wspomaganiu rozwoju dziecka z uszkodzonym słuchem. W: E. Domagala-Zyśk, A. Borowiec, R. KoŁodziejczyK (red.), Język i wychowanie. Księga jubileuszowa z okazji 45-lecia pracy naukowej Profesor Kazimiery Krakowiak (s. 306-320). Lublin: Wydawnictwo KUL.

Marcinkowska, J. (2009). Rozwój dziecka głuchego. W: M. Kowalska (red.), Moje głuche dziecko. Kompendium wiedzy na temat rehabilitacji dziecka głuchego (s. 29-35). Łódź: Polski Związek Głuchych/Oddział Łódzki.

TręBicka-Postrzygacz, B. (1999). Dziecko niesłyszące w rodzinie. Audiofonologia, 14, 93-101.

Zaidman-Zait, A., Most, T., TARrasch, R., Haddad-EID, E., Brand D. (2016). The impact of childhood hearing loss on the family: Mothers' and fathers' stress and coping resources. The Journal of Deaf Studies and Deaf Education, 21(1), 23-33. DOI: 10.1093/deafed/env038.

Ziemska, M. (1973). Postawy rodzicielskie. Warszawa: Wiedza Powszechna.

ZIEMSKA, M. (1981). Kwestionariusz dla rodziców do badania postaw rodzicielskich: podręcznik tymczasowy. Warszawa: Państwowe Wydawnictwo Naukowe.

\section{OJCOSTWO W SAMOOCENIE MEŻZZYYN \\ WYCHOWUJĄCYCH DZIECI Z USZKODZONYM SŁUCHEM \\ CZĘŚĆ II. BADANIA EMPIRYCZNE}

\section{STRESZCZENIE}

Ojcostwo wobec dziecka niesłyszącego jest dużym wyzwaniem, natomiast uwaga badaczy i praktyków skupia się głównie na przeżyciach i roli matki. Dlatego należy z uznaniem odnotować wzrastającą liczbę doniesień naukowych na temat doświadczeń ojca w tej sytuacji, jego ojcowskiej roli i znaczenia jego zaangażowania w wychowanie dziecka. Artykuł prezentuje wyniki badań w grupie 14 ojców metodą sondażu diagnostycznego przy użyciu kwestionariusza ankiety własnej konstrukcji oraz Kwestionariusza dla Rodziców M. Ziemskiej.

Na podstawie wyników badań można stwierdzić, że ojcowie dzieci niesłyszących rozumieją ojcostwo jako odpowiedzialność za dziecko i obowiązek zaspokojenia jego potrzeb; oceniają siebie jako dobrych ojców; w większości starają się wspomagać rozwój swojego dziecka poprzez uczestniczenie w jego codziennych czynnościach, rehabilitacji, w ważnych wydarzeniach życiowych i wpajaniu hierarchii wartości, ale żonie przypisują znacznie większą rolę w codziennym życiu dziecka oraz we wspieraniu go emocjonalnym; postrzegają swoje dziecko z uszkodzeniem słuchu jako samodzielne, jednak potrzebujące więcej opieki i troski niż dziecko słyszące; ojcowie różnią się w zakresie postaw rodzicielskich, niektórzy przyjmują postawę nadmiernego góro- 
wania, kontrolowania i bezradności, połowa z nich charakteryzuje się postawą dystansu. Niewątpliwie ojcowie, tak jak i pozostali członkowie rodziny (a właściwie rodzina jako system), wymagają różnorodnych form pomocy i wsparcia, w tym również psychologicznego.

Słowa kluczowe: niepełnosprawność słuchowa; dziecko niesłyszące; ojciec dziecka niesłyszącego; samoocena roli rodzicielskiej ojca dziecka niesłyszącego.

\title{
SELF-ASSESSMENT OF PATERNITY IN MEN RAISING CHILDREN WITH IMPAIRED HEARING
}

\author{
PART II. EMPIRICAL RESEARCH
}

\section{SUMMARY}

Paternity to a deaf child is a big challenge, while the attention of researchers and practitioners focuses mainly on the experiences and role of the mother. Therefore, the increasing number of scientific reports on the experiences of the father in this situation, his paternal role and the importance of his involvement in the upbringing of the child should be noted with appreciation. The article presents the results of 14 fathers' research by means of a diagnostic survey using a selfassessment questionnaire and M. Ziemska's Parents' Questionnaire. On the basis of the research results it can be concluded that fathers of deaf children understand paternity as a responsibility for the child and a duty to meet its needs; they evaluate themselves as good fathers; most of them try to support the development of their child by participating in its everyday activities, rehabilitation, important life events and instilling the hierarchy of values, but they attribute to their wife a much greater role in the child's everyday life and in supporting it emotionally; they perceive their child with hearing loss as independent, yet in need of more care and attention than a child with hearing loss; fathers differ in parental attitudes, some adopt an attitude of over-abundance, control and helplessness, half of them with an attitude of distance. Undoubtedly, fathers, like the rest of the family (or rather the family as a system), require various forms of help and support, including psychological support.

Key words: hearing impairment; deaf child; father of a deaf child; self-assessment of the parental role of the father of a deaf child. 